го захисту населення України від 29.07.1993 № 58 [Електронний ресурс]. Режим доступу: http://zakon2.rada.gov.ua/laws/show/z0110-93.

6. Кодекс законів про працю України. Закон України від 10.12.1971 № 322-VIII. Biдомості Верховної Ради УРСР від 17.12.1971 1971. Додаток до № 50.

7. Конституція України. Закон України від 28.06.1996 № 254к/96-ВР. Відомості Верховної Ради Украӥни (ВВР). 1996. № 30. с. 141.

8. Калужный С.А. Объяснение нарушителя трудовой дисциплины. Известие высших учебных заведений. Правоведение. 1986. № 6. С. 67-70.

УДК 349.2

DOI https://doi.org/10.32844/2618-1258.2019.5-2.20

ЧУМАЧЕНКО І.М.

\title{
ДО ПРОБЛЕМИ ВИЗНАЧЕННЯ ВИДІВ ПРОЦЕСУАЛЬНИХ ПРАВОВІДНОСИН У ТРУДОВОМУ ПРАВІ УКРАЇНИ
}

\begin{abstract}
У статті на основі аналізу наукових поглядів вчених відзначається, що залежно від галузі права правники по-різному підходять до класифікації процесуальних правовідносин. Розглянуто думки фахівців із галузі трудового права на окреслену проблематику. Запропоновано власне бачення щодо видів процесуальних правовідносин у трудовому праві України, однак при цьому відмічено, що здійснений у статті поділ правовідносин може змінюватись у процесі вдосконалення останніх. 3'ясовано, що питання вирішення колективних трудових спорів регулюються нормами, які визначені в Законі України «Про порядок вирішення колективних трудових спорів (конфліктів)». Відповідно до вказаного Закону під колективним трудовим спором необхідно розуміти розбіжності, що виникли між сторонами соціально-трудових відносин щодо: 1) встановлення нових або зміни наявних соціально-економічних умов праці та виробничого побуту; б) укладення чи зміни колективного договору, угоди; в) виконання колективного договору, угоди або окремих їх положень; г) невиконання вимог законодавства про працю. Зроблено висновок, що в юридичній літературі ще й досі не визначеного єдиного підходу щодо класифікації процесуальних правовідносин, саме тому на основі аналізу наукових поглядів вчених та норм чинного законодавства України запропоновано класифікувати дані правовідносини таким чином: 1) залежно від виду трудового спору: а) щодо вирішення індивідуальних трудових спорів. б) щодо вирішення колективного трудового спору; 2) залежно від суб'єкта, що вирішує трудовий спір; 3) залежно від цілей вирішення трудового спору: а) правовідновлюючі; б) каральні; в) компенсаційні; 4) залежно від мети, функцій та завдань процесуальних правовідносин: а) регулятивні (правовстановлюючі); б) охоронні; 5) з урахуванням структури змісту правовідносини можуть бути поділені на: прості та складні. Звісно, запропонована нами класифікація процесуальних правовідносин у трудовому праві не претендує на повноту та вичерпність, а здійснений нами поділ правовідносин може змінюватись у процесі вдосконалення останніх.
\end{abstract}

Ключові слова: правовідносини, прочесуальні правовідносини, трудове право Украӥни, вид, класифікації.

In the article, based on the analysis of scientific views of scientists, it is noted that, depending on the field of law, lawyers differently approach the classification of procedural legal relations. Opinions of experts in the field of labor law on the outlined problems

(C) ЧУМАЧЕНКО І.М. - доктор юридичних наук, доцент, професор кафедри цивільного права (Запорізький національний університет) 
are considered. The own vision of the types of procedural legal relations in the labor law of Ukraine is offered, but it is noted that the division of legal relations made in the article may change in the process of improvement of the latter. It has been found out that the issues of resolving collective labor disputes are governed by the norms set out in the Law of Ukraine "On the Procedure for the Settlement of Collective Labor Disputes (Conflicts)". According to the said Law, the collective labor dispute must be understood as differences arising between the parties of social and labor relations, regarding: a) establishment of new or change of existing socio-economic conditions of work and industrial life; b) conclusion or amendment of a collective agreement, agreement; c) implementation of a collective agreement, agreement or their separate provisions; d) failure to comply with labor law requirements. It is concluded that the legal literature has not yet defined a unified approach to the classification of procedural legal relations, which is why, on the basis of the analysis of scientific views of scientists and norms of the current legislation of Ukraine, it is proposed to classify the following legal relations as follows: 1) depending on the type of labor dispute: a) to resolve individual labor disputes; b) to settle a collective labor dispute; 2) depending on the entity that resolves the labor dispute; 3 ) depending on the purposes of the settlement of the labor dispute: a) restorative; b) punishments; c) compensation; 4) Depending on the purpose, functions and tasks of the procedural legal relations: a) regulatory (legal); b) security; 5) taking into account the structure of the content of the legal relationship can be divided into: simple and complex. Of course, our classification of procedural legal relations in labor law does not claim to be complete and comprehensive, and the division of legal relations we have performed may change in the process of improving the latter.

Key words: legal relations, procedural legal relations, labor law of Ukraine, type, classifications.

Вступ. Одним із головних завдань України як демократичної, правової, соціальної держави $€$ всебічне забезпечення прав, свобод і законних інтересів людини та громадянина. Задля цього держава запроваджує відповідні політичні, юридичні, соціальні та інші гарантії, а також створює організаційно-правові механізми, що забезпечують практичну реалізацію цих гарантій. Після проголошення незалежності та обрання нового курсу розбудови державності в Україні було запроваджено цілу низку реформ і перетворень, спрямованих на вдосконалення означених механізмів, їх перетворення з урахуванням проголошених пріоритетів та принципів. Однак, незважаючи на це, слід констатувати, що низка важливих питань у частині зміцнення гарантій основоположних прав людини і громадянина все ще залишається невирішеною, зокрема це стосується прав і законних інтересів у сфері праці.

Серед інших проблемних питань у сфері використання найманої праці досить гострим $\epsilon$ недосконалість процесу захисту трудових прав і законних інтересів працівників, на чому неодноразово наголошували раніше та продовжують акцентувати увагу сьогодні як теоретики права, так і представники юридичної практики. Відсутність чіткої та змістовної законодавчої регламентації основних юридичних аспектів процесуальних відносин у трудовому праві, які супроводжують вирішення трудових спорів, негативним чином позначається на ефективності та дієвості передбачених державою гарантій для найманих працівників. Прогалини та інші недоліки в зазначеному законодавстві, у свою чергу, зумовлені як низькою якістю роботи законотворчих органів, так і слабким науково-теоретичним обгрунтуванням даної проблематики. Сьогодні вирішення всіх проблемних питань у сфері правового регулювання процесуальних правовідносин потребує перегляду теоретико-методологічних засад вказаного інституту. Зокрема, в цьому контексті не можна оминути увагою питання класифікації процесуальних правовідносин.

Стан дослідження. Окремі теоретичні аспекти процесуальних правовідносин у трудовому праві розглядали у своїх наукових працях ряд науковців, зокрема: В.М. Юрчишин, А.М. Нечаева, О.В. Чернецька, Д.В. Боброва, О.В. Дзера, А.С. Довгерт, А.О. Івченко, В.І. Шинкарук, Ф.В. Константинов, В.В. Жернаков, С.М. Прилипко, О.М. Ярошенко, С.І. Запара, В.О. Кабанець, Д.В. Шевченко, В.В. Лазор та багато інших. Однак, незважаючи на чималу кількість наукових розробок, в юридичній літературі відсутнє єдине комплексне дослідження, присвячене визначенню видів процесуальних правовідносин у трудовому праві України, що є суттєвою прогалиною на теоретичним та практичному рівнях. 
Постановка завдання. Саме тому мета статті - визначити види процесуальних правовідносин у трудовому праві України.

Результати дослідження. Починаючи розгляд основного питання, що визначено у представленій науковій роботі, відзначимо, що в юридичній літературі не існує єдиного підходу щодо класифікації процесуальних правовідносин взагалі та у трудовому праві зокрема. Залежно від галузі права вчені по-різному підходять до класифікації процесуальних правовідносин. Так, С.В. Васильєв, визначаючи види цивільних процесуальних правовідносин, пропонує їх класифікувати таким чином: 1) за обов'язковим суб'єктом: відносини між судом першої інстанції і всіма особами, які беруть участь у розгляді справи; відносини між судом другої інстанції і зацікавленими особами; відносини між судом касаційної інстанції і зацікавленими особами; відносини між вищестоящими і нижчестоящими судовими органами; 2) залежно від підрозділів: головні (основні) - складаються між судом і стороною, судом і заявником; додаткові - складаються між судом і третьою особою, прокурором, органами державного управління; службово-допоміжні складаються між судом і свідком, експертом, перекладачем [1].

Досить розгорнуто до класифікації процесуальних правовідносин в адміністративному праві підійшов В.Г. Перелюк, який доводить, що адміністративно-процесуальні правовідносини можна класифікувати за такими підставами [2]: 1) за змістом. Розподіл адміністративно-процесуальних правовідносин за змістом $\epsilon$ комплексним. Одна група правовідносин, врегульованих адміністративно-процесуальним правом, не зв'язана безпосередньо з реалізацією якої-небудь функції держави, іххній зміст носить загальний характер; 2) за видами адміністративного провадження. Така класифікація відображає складну структуру адміністративного процесу. Значне число цих справ, їхню розмаїтість зумовлюють об'єктивні потреби в об'єднанні цих справ за видами провадження, виходячи з характеру кожної даної категорії індивідуально-конкретних справ у сфері державного управління; 3) за галузевою належністю кореспондуючих матеріальних правовідносин. Зазначене грунтується на тому, що в даному випадку існує не окреме, ізольоване адміністративно-процесуальне правовідношення, а система відносин, де адміністративно-процесуальне правовідношення виступає в якості одного з її елементів. Дана система складається із трьох елементів: 1) фактичні суспільні відносини, 2) матеріальне компетенційне правовідношення, що закріплює фактичні суспільні відносини, і 3) адміністративно-процесуальне правовідношення. Між цими елементами, безсумнівно, є тісний зв'язок. Кожний із них відносно самостійний і володіє визначеними специфічними властивостями; 4) за співвідношенням прав і обов'язків їхніх учасників [2].

B.Е. Теліпко та О.Г. Дутова зазначають, що при різних видах провадження у справах про трудові спори виникають різні види процесуальних правовідносин: трудові процесуальні (КТС), цивільно-процесуальні (загальні суди) і адміністративно-процесуальні (наприклад, щодо звільнення з посад, віднесених до категорій посад державної служби). Кожне визначається відповідно до того юрисдикційного органу, який розглядає трудовий спір. Причому, підкреслюють науковці, один спір може бути пов'язаний одночасно, як мінімум, із двома видами процесуальних відносин, за умови, наприклад, послідовного розгляду спору спочатку в КТС із подальшим перенесенням його до суду. Однак тут, на переконання В.Е. Теліпка та О.Г. Дутової, важливо відзначити, що, попри це, спір у всіх процесуальних відносинах вирішується виключно на підставі норм матеріального трудового права [3, с. 366]. Із таким твердженням вказаних вище науковців складно погодитись, адже, на нашу думку, існує значно більше критеріїв для класифікації процесуальних правовідносин у трудовому праві.

Тож, узагальнюючи вказані вище точки зору, вважаємо, що можемо запропонувати власне бачення класифікації процесуальних правовідносин. Першою класифікаційною ознакою є поділ процесуальних правовідносин залежно від виду трудового спору, який, у свою чергу, може бути колективними та індивідуальними. Колективний трудовий спір, як зазначає М.П. Стадник, - це неврегульовані розбіжності, які виникають між трудовим колективом найманих працівників підприємства, установи, організації, їхніх структурних підрозділів і роботодавцем із питань встановлення нових або зміни наявних соціально-економічних умов праці і виробничого побуту, укладення, зміни, виконання колективних договорів, різного тлумачення законодавства та інших нормативних актів [4]. А.Д. Зайкін доводить, що колективний трудовий спір - це неврегульовані суперечності між працівниками і роботодавцями із приводу встановлення та зміни умов праці (включаючи заробітну плату), укладання, зміни й виконання колективних договорів, угод із питань соціально-трудових відносин» $[5$, с. $364 ; 6]$. Отже, колективний трудовий спір - це така стадія вирішення неврегульованих у процесі колективного трудового конфлікту розбіжностей між 
трудовим колективом та роботодавцем, їхніми організаціями чи представниками щодо встановлення, зміни або застосування умов праці та соціально-побутового обслуговування працівників, за якої розгляд цих розбіжностей передається до визначеного законодавством юрисдикційного органу [7, с. 13]. Питання вирішення колективних трудових спорів регулюються нормами, які визначені в Законі України «Про порядок вирішення колективних трудових спорів (конфліктів)». Відповідно до вказаного Закону під колективним трудовим спором необхідно розуміти розбіжності, що виникли між сторонами соціально-трудових відносин щодо: а) встановлення нових або зміни наявних соціально-економічних умов праці та виробничого побуту; б) укладення чи зміни колективного договору, угоди; в) виконання колективного договору, угоди або окремих їх положень; г) невиконання вимог законодавства про працю [8].

Що ж стосується індивідуальних трудових спорів, то з точки зору А.Г. Мостовщікова індивідуальний трудовий спір - це неврегульована розбіжність, що виникає між суб'єктами трудових правовідносин у зв'язку із застосуванням законодавства про працю, локальних нормативних правових актів, що переростає у трудовий конфлікт, який вирішується в установленому законом порядку в КТС або судових органах [9, с. 30].

Досить розгорнуте визначення поняття «індивідуальний трудовий спір» надає К.Ю. Мельник, який під вказаним терміном пропонує розуміти неврегульовані розбіжності між роботодавцем і працівником (претендентом на посаду, звільненим працівником) із питань застосування трудового законодавства, колективних угод, локальних нормативно-правових актів, трудового договору або встановлення чи зміни індивідуальних умов праці, про які заявлено в орган (посадовій особі), наділений відповідними повноваженнями з їх вирішення [10, с. 410]. Вчений зазначає, що порядок вирішення індивідуальних трудових спорів має низку особливостей: по-перше, такий порядок регламентований нормами трудового та цивільного процесуального законодавства; по-друге, поряд із судами індивідуальні трудові спори можуть розглядати спеціально створені органи - комісії із трудових спорів, а також інші органи та посадові особи, передбачені законодавством; по-третє, у вирішенні індивідуального трудового спору можуть брати участь представники профспілок. Індивідуальні трудові спори розглядаються: 1) комісіями із трудових спорів; 2) районними, районними у місті, міськими чи міськрайонними судами. Такий порядок розгляду трудових спорів, що виникають між працівником і роботодавцем, підкреслює К.Ю. Мельник, застосовується незалежно від форми трудового договору. Разом із тим зазначений порядок розгляду трудових спорів не поширюється на спори про дострокове звільнення від виборної платної посади членів громадських та інших об'єднань громадян за рішенням органів, що їх обрали [10, с. 410]. Отже, виокремлення такого критерію класифікації процесуальних правовідносин у трудовому праві, як залежно від виду трудового спору, зумовлюється тим, що під час вирішення різних трудових спорів (індивідуальних чи колективних) застосовуються різні процесуальні норми.

Наступною класифікаційною ознакою, відповідно до якої слід поділяти процесуальні правовідносини у трудовому праві, є «залежно від суб'єкта, що вирішує трудовий спір» (комісія із трудових спорів, трудовий арбітраж, примирні комісії). Слід відзначити, що незалежно від суб'єкта спір у всіх процесуальних відносинах вирішується виключно на підставі норм матеріального трудового права. У цьому контексті всі види розгляду трудових спорів - це процес, тобто особлива форма застосування норм трудового права уповноваженим на те юрисдикційним органом під час розгляду ним трудових спорів. При цьому кожен із трьох видів процесуальних правовідносин із розгляду трудових спорів визначається за тим юрисдикційним органом, який розглядає спір. Таким чином, вид процесуальних відносин залежить саме від органу, що розглядає спір, до розв'язання якого незалежно від виду процесу будуть застосовані норми матеріального трудового права, на що було вказано вище [3, с. 366].

Далі розглянемо процесуальні правовідносини у трудовому праві, які залежно від цілей вирішення трудового спору слід поділяти на: а) правовідновлюючі; б) каральні; в) компенсаційні. Правовідновлюючі процесуальні правовідносини спрямовані на відновлення незаконно порушених прав, примусове виконання невиконаних обов'язків, властивих цивільній, насамперед майновій відповідальності (відновлення майнового права). Вказані правовідносини мають абсолютно визначений характер, тобто в них чітко окреслюється розмір заподіяної шкоди, який може бути точно встановлений незалежно від обставин правопорушення, - спрямована на виховання громадян у дусі поважання закону [11, с. 436]. Що ж стосується каральних процесуальних правовідносин, то вони спрямовуються на те, щоб застосувати заходи покарання до осіб, які спричинили порушення трудових прав інших працівників. І останній вид процесуальних правовідносин у трудовому праві, які слід вказати в рамках представленої класифікаційної ознаки, - компенса- 
ційні, які представляють собою правовідносини, що спрямовані на відшкодування шкоди матеріального характеру.

Залежно від мети, функцій та завдань процесуальних правовідносин у трудовому праві: a) регулятивні (правовстановлюючі); б) охоронні. Будь-які правовідносини, в тому числі і процесуальні, у своїй більшості є регулятивними, оскільки опосередковують (регулюють) позитивну поведінку суб'єктів відповідно до норм права. Формально-юридичною підставою такі процесуальні правовідносини мають відповідні регулятивні норми законодавства і виникають за наявності певних юридичних фактів. Разом із тим серед правовідносин значне місце займають i охоронні, які служать засобом реалізації охоронних норм права. Ці процесуальні правовідносини виникають із фактів вчинення протиправної поведінки учасників суспільних відносин, яка потребує певної реакції з боку суспільства і держави в особі уповноважених органів чи інших уповноважених суб'єктів. Такі правовідносини звичайно пов'язані з виникненням та застосуванням юридичної відповідальності, передбаченої в санкціях охоронних правових норм [12].

I остання класифікаційна ознака, за якою, на нашу думку, можна поділити процесуальні правовідносини у трудовому праві, - 3 урахуванням структури змісту правовідносини: прості та складні;

Висновки. Отже, завершуючи представлене наукове дослідження, відзначимо, що в юридичній літературі ще й досі не визначений єдиний підхід щодо класифікації процесуальних правовідносин, саме тому на основі аналізу наукових поглядів вчених та норм чинного законодавства України нами було запропоновано класифікувати дані правовідносини таким чином: 1) залежно від виду трудового спору: а) щодо вирішення індивідуальних трудових спорів. б) щодо вирішення колективного трудового спору; 2) залежно від суб'єкта, що вирішує трудовий спір; 3) залежно від цілей вирішення трудового спору: а) правовідновлюючі; б) каральні; в) компенсаційні; 4) залежно від мети, функцій та завдань процесуальних правовідносин: а) регулятивні (правовстановлюючі); б) охоронні; 5) з урахуванням структури змісту правовідносини можуть бути поділені на: прості та складні. Звісно, запропонована нами класифікація процесуальних правовідносин у трудовому праві не претендує на повноту та вичерпність, а здійснений нами поділ правовідносин може змінюватись у процесі вдосконалення останніх.

\section{Список використаних джерел:}

1. Васильєв С.В. Цивільний процес України : навчальний посібник. Київ : «Центр учбової літератури», 2013. 344 с.

2. Перепелюк В.Г. Адміністративний процес. Загальна частина : навчальний посібник. Чернівці : Рута, 2003. 367 с.

3. Теліпко В.Е., Дутова О.Г. Трудове право України : навч. посіб. / За заг. ред. Теліпко В.Е. Київ : Центр учбової літератури, 2009. 456 с.

4. Стадник М.П. Правове регулювання вирішення колективних трудових спорів (конфліктів) : автореф. дис. ... канд. юрид. наук : 12.00.05 / Інс-т д-ви і права ім. В.М. Корецького. Київ, 1998. 16 с.

5. Российское трудовое право / Под ред. А.Д. Зайкина. Москва : НОРМА, 1997. 415 с.

6. Єрохін С.В. Роль посередництва у вирішенні колективних трудових спорів (конфліктів) : дис... канд. наук : 12.00.05. 2008. $180 \mathrm{c}$.

7. Рибницький Г.В. Колективний договір в умовах ринкової економіки : автореф. дис... канд. юрид. наук : 12.00.05 / Національний ун-т внутрішніх справ. Харків, 2005. 19 с.

8. Про порядок вирішення колективних трудових спорів (конфліктів) від 03.03.1998 № 137/98-BP. URL : http://zakon.rada.gov.ua/laws/show/137/98-вр/conv.

9. Мостовщиков А.Г. Порядок рассмотрения индивидуальніх трудовіх споров : дис. ... канд. юрид. наук : 12.00.05. Томск, 2004. 193 с.

10. Мельник К.Ю. Трудове право України : підручник. Харків : Діса плюс, 2014. 480 с.

11. Скакун О.Ф. Теорія держави і права : підручник. Харків : Консум, 2001. 656 с.

12. Віхров О.П., Віхрова І.О. Теорія держави і права: курс лекцій: навчальний посібник. Чернігів : Десна Поліграф, 2015. 304 с. 